\title{
Towards Excellence
}

\section{SPORTS AS A POLITICAL ARENA: SOME REFLECTIONS}

\author{
Dr. H. P. Solanki
}

\section{Abstract:}

Since the last few decades the political interventions in sports have increased to a great extent and have made sports as a political arena. This is a dangerous sign of a healthy sportsman spirit. Sport is now no longer a celebration of athletes' great victory and heart-warming stories, but it seems a victory of false on truth or a victory of politics over the goodness of sport. Politics has rotten the soul of sports. Leaders, autocrats, and powerful individuals have been using sports to assert their political dominance. It has been noticed that when the sportsperson's join certain political parties, they turn as a face of that political party than the reflection of true sportsman spirit. This paper attempts to highlight different ways using which politics has entered in the sports. This paper discusses some significant strategies through which sports are becoming a political arena in India.

Keywords: Politics, Sports, Nepotism, Casteism, Favouritism

\section{Introduction:}

Cambridge Online Dictionary defines sports as "all types of physical activity that people do to keep healthy or for enjoyment" or as "a game, competition, or activity needing physical effort and skill that is played or done accordingly to rules, for enjoyment and/or as a job." ${ }^{1}$ These definitions make it clear that the sole aim of sports is to have fun or entertainment. During earlier times, sports used to be very simple. The games were played to have fun or entertainment. But now the idea of sports has changed significantly. It is much more than mere fun and entertainment. Every level of sports, whether it is a village match or an international pro-league, politics has entered in and made sports a business that aspires to generate money and influence. History shows that political interference in sports has both positive and negative impacts. While sports have been successful in creating a nation fervor 
Towards Excellence: An Indexed, Refereed \& Peer Reviewed Journal of Higher Education / Dr. H.P. Solanki/ Page 60-68

amongst the audience, it has also created tension among countries. For example, an international cricket match between the teams of India and Pakistan has united the audience in the name of the nation in both these countries, but such a match has always aired the flame between these countries.

In this paper, I have tried to note down some reflections over the sports as a political arena. My task in this paper would be to show the political implication and their role in sports.

\section{- Cheer Leaders}

The entry of cheerleaders in sports marks the entry of the gendered and economic politics in sports. Laura Grindstaff and Emily West, in their article, "Cheerleading and the Gendered Politics," observed that "Cheerleading is a space where the doing and displaying of gender are particularly visible, and where the gender regimes represented by hegemonic masculinity and emphasized femininity are being negotiated and resecured in the face of alternative regimes. It is a place where the boundaries of gender difference are crossed as well as preserved."2 In India too, the recent phenomenon of hiring the cheerleaders has its base in the hegemonic masculinity and Indian male's love for 'foreign fair' women more than the entertainment through sports. It employs economic politics in the sense that the cheerleaders are hired to attract the males so that the vacant seats of playgrounds or courts could be filled with higher ticket rates. In doing this, the organizers of the sports event that have cheerleaders have forgotten about the safety measures for the foreign cheerleaders. This issue came to the front when in 2015, some cheerleaders acknowledged that "We sometimes get a trash thrown at us. I just ignore it" or "I put a blank stare on for the most part when I'm facing the crowd. There's just so many nasty men making kissy faces and taking my picture that I tend to just block it all out." 3 Though it is the fact that the cheerleaders are earning handsome amount for cheerleading in tight-short clothes, this is the Bollywood inspired mechanism to attract more audience in IPL cricket matches.

- Nepotism

Like many other spheres, the sports have witnessed nepotism in many games and tournaments. Recently the former Indian cricketer Aakash Chopra agreed to a fact that, though nepotism at its highest level is not visible in Indian cricket, there are certain cases which indicate that nepotism is seen at some lower levels of domestic cricket. On his Youtube show Akashvaani, he claimed that "I have seen it happening in a state team where a player 
was a captain for a long time. He was an administrator's son, not a player's. He was not a very good player and his stats also show it. But at the highest level, it never happens. No one is given an IPL contract because he is someone's friend's son or someone's nephew." Aakash said on his Youtube show AakashVani. However, R M Lodha, the former Chief Justice of India and the Chairman of the Lodha Committee of $\mathrm{BCCl}$, in one of his interview with Jitendra Gupta of OUTLOOK, reported that "I think it $(\mathrm{BCCl})$ is suffering from the same problems, same diseases, same ailments as the $\mathrm{BCCl}$ has been suffering from -- corruption, nepotism, non-accountability, non-transparency, huge and unlimited discretionary powers with administrators, and mismanagement of revenue and financial matters. They are the same problems that were happening with the $\mathrm{BCCl}$. They all, obviously, need some good solutions." 5 Not only cricket but in other fields as well there are complaints of nepotism. In 2018, the Indian Olympic Association of India had to cut short the list of the athletes of Asian Games because of accuses of nepotism.

\section{- Casteism}

Casteism has entered in all the facets of Indian life. Event sports have not remained untouched by the caste politics. Earlier there was a representation from the Indian downtrodden communities in sports but now hardly a few players or the athletes represent the unprivileged castes in sports in India. Ramchandra Guha, in his book, Democracy's XI, found that some Dalit and Adivasi cricketers had represented India. However in another book by Ramchandra Guha, A Corner in a Foreign Field, narrates the plight of a great Dalit cricketer of Mumbai, Palwankar Baloo, during the pre-independence time who was forced to sit apart from the rest of his team-mates during the tea break. Rajdeep Sardesai claims that even in the post-independence era as well, especially till the 1970s, Indian cricket remained primarily an upper caste with a few exceptions like Eknath Solkar. Rajdeep Sardesai further claims that "It is only in post-liberalization India, that there have been visible signs of change: agrarian middle castes like the Yadavs now have a greater representation, perhaps in keeping with their improved political and economic status. And the spread of the game to remote corners through cricket academies has thrown up exciting possibilities."6 Rajdeep Sardesai, providing the numbers of the cricketers who have represented India at the international level, claims that "since 1932, 290 individuals have worn the India cap but there are only three Dalits who have played for the country and no Adivasi, a striking anomaly that reflects how India's premier mass sport is still monopolized by elite groups."7 An article published in Economic and Political Weekly appealed that the selectors should select the cricketers from the humble 
Towards Excellence: An Indexed, Refereed \& Peer Reviewed Journal of Higher Education / Dr. H.P. Solanki/ Page 60-68

background employing the strategy of South Africa wherein the selectors have to select at least the six players of colour. Ramdas Athawale, a Dalit and minister for social justice in the Narendra Modi government, supports the idea of reservations in sports as affirmative action to have a balanced representation from all the varnas. He said, "If we have reservations in jobs and higher education, then logically cricket, and other sports, should be included too, for the same reason of historical discrimination." 8 This is a famous truth that Vinod Kambli, the well-known Indian middle-order batsman who made his Test debut in 1993 and played his last one-day international in 2000 hated any mention of his caste. A dalit columnist Chandra Bhan Prasad argued that "It's not as if there are people (selectors) standing with rods preventing dalits from becoming cricketers." $\mathrm{He}$ added that "It's just that a dalit will have to be twice as good as a high caste person even to be considered. If there are no dalits in cricket, shouldn't the selectors be asking why? And doing something about it?"10 Even Udit Raj, a dalit Member of Parliament representing Congress Party also supported the idea of reservation in the national cricket team on a model of South Africa. He said, "It's the only way to smash the domination of the upper castes in every sphere of life. Selectors say only merit counts but that is rubbish. Dalit cricketers never get to the point where they can even demonstrate their merit". ${ }^{11}$ Citing the case of Abhishek Jhatav, a young dalit in Nizampur village in Uttar Pradesh, Udit Raj that Jhatay "loved cricket as a young boy and played for his school but moving on to district level was impossible". Quoting Jhatay, Udit Raj says "The nearest cricket ground is 50 kilometres away. There are no training facilities or coaching centers so even though I was very good, what more could I do? It doesn't matter how talented I might be. I'm not going to get anywhere." ${ }^{2}$ Thus, the entry in Indian sports needs a highcaste background in many cases.

- Urban vs. Rural

A struggle between the athletes or the players of the urban and rural background is observed at different levels. If we look at the make-up of the Indian cricket team in the present times, the team is blessed with a far greater regional mix that ever before. However, it is found that the Indian cricket team is over-represented by the boys from big cities like Mumbai. Ramchandra Guha points out that "the "small town" revolution in Indian cricket has meant that the Indian ODI XI in England only had three players - Virat Kohli, Rohit Sharma, and Shikhar Dhawan - who could be described as "metro men": the rest have all learnt their cricket in B town, tier 2 India." 13 This should be remembered that the greater interest in the sports have 
Towards Excellence: An Indexed, Refereed \& Peer Reviewed Journal of Higher Education / Dr. H.P. Solanki/ Page 60-68

encouraged the people from diversified background to represent India. Thus, now the national teams of different sports and athletics are a mixture of both humbled and privileged and this is becoming a 'new normal' in Indian sports. For example, Umesh Yadav, whose father was a coal mine labourer, and K. L. Rahul, whose father an NIT engineering professor, both share the dressing room. This shows that Indian cricket is bringing the men from different social backgrounds together and this is mobilizing the society. IPL cricket tournaments have succeeded in bringing this change, however, in many sports, it has been observed that the athletes or the players living the remote village do not get any facility for the practice in comparison to those living in the city areas. Consequently, those who are city-bred have more chances than those who are from villages.

- Favouritism

Favoritism in the selection process has been discussed rigorously so far. Yuvraj Singh, the Former Indian all-rounder described Suresh Raina as M. S. Dhoni's favorite player. Singh told that every captain has a certain favorite player in his side and MS Dhoni's case, he always backed Suresh Raina's selection. Coincidently, Raina was a regular member of the Indian team until M. S. Dhoni retired as India's ODI and T20I captain at the start of 2017. While speaking to FanCode, Suresh Raina acknowledged that while M. S. Dhoni has always supported him, it is because of his abilities. ${ }^{14}$ These kinds of accusations are quite common in different sports in India. At the international level as well, the International Cricket Council (ICC) is often accused of treating Asian players differently than others. Sunil Gavaskar repeatedly accused ICC of double standards when it is matter punishing Asian players. Mentioning the India-Australia series in 2008, Gavaskar told that Virender Sehwag was given not out on an appeal for leg-before-wicket, the then Australian skipper, Ricky Ponting, went up to the umpire and kept on inquiring about the decision which was uncalled for but the incident went unnoticed. ${ }^{15}$ Thus, favouritism is observed at regional, national, and international levels.

\section{- Political Interference}

Often it is remarked that in India, a great pool of talented sportspersons is not been able to make a mark on the international stage despite the government's efforts and spending on the development of different games-sports and the infrastructure for them. Though India has a diverse sporting culture ranging from traditional sports such as Kabaddi to colonized sports such as Cricket, India lags far behind from many countries in sports because of the high levels of corruption and discrimination in sports. The sports federations and associations in India 
have their office bearers who are politicians or businessmen. Most of the sports federations and associations in India, including the Board of Control for Cricket in India (BCCl), are politically dominated organizations that have overlooked the talent in sports and games. While commenting on the degrading standards of hockey in India, a bench of the Supreme Court comprising Justice T.S. Thakur and Justice Chelameshwar, observed that "It is a sad commentary that people who are administrators of the game have nothing to do with sports and they run the bodies at the cost of the game. Sports are run by private individuals. Private individuals are controlling the games in India. Can the game be held hostage by private interest? This is why hockey has come down and the team is struggling to qualify for the Olympics where we used to win gold medals." 16 Political persons heading the sporting federations often change the rules for the administration of such federations so that they can be profit-making to them. Instead of bringing, some qualitative reforms in the federations they are heading, they often look at sites of corruption so that they may grow prosperous. Thus, political interference causes a problem in bringing the talent to the front in India.

- Rigid Policies and their Implementations

Due to the political structures of federations, the rigid policies and their implementations are still prevalent in India. Some of the rigid policies in the selection of the heads of such federations promote corruption and hinders the true motive of sports. For the development of any sector, the formulation and execution of an effective policy is the most important aspect. This is true for sports also. To date, the sports policy planning and implementation are centralized in the country due to the paucity of resources and the expertise by the State and local governments.

\section{- Lack of Infrastructure}

India lags behind many countries in sports despite good prospective athletes and players because of the lack of the necessary infrastructure. As we all know that India lives in its villages. There are possibilities many good players coming out of the villages, but in villages and many nearby cities, there is no infrastructure related to sports. This is one of the most important factors for the apathy of the sport in India. Since infrastructure is necessary for training and organizing games, its non-availability and its access to only a few sections of the society have adversely impacted the sport participation and the quality of sportspersons. Due to the government's policies, the management of available infrastructure is not carried out efficiently. 
Towards Excellence: An Indexed, Refereed \& Peer Reviewed Journal of Higher Education / Dr. H.P.

\section{Solanki/ Page 60-68}

Conclusion:

Thus, it can be argued that the political interventions at the different levels in sports have increased to a great extent and have made sports as a political arena. Though this proves to be a perilous sign for the healthy sportsman spirit, no adequate steps are taken to control this menace. The entry of politics has rotten the true spirit of sports. Leaders, autocrats, and powerful individuals have been using sports to assert their political dominance. It has been noticed that when the sportsperson's join certain political parties, they turn as a face of that political party than the reflection of true sportsman spirit. 
Towards Excellence: An Indexed, Refereed \& Peer Reviewed Journal of Higher Education / Dr. H.P. Solanki/ Page 60-68

\section{References}

1. Online Cambridge Dictionary: https://dictionary.cambridge.org/dictionary/english/sport

2. Grindstaff, Laura, and Emily West. "Cheerleading and Gendered Politics." Social Problems 53.4. 2006. https://www.jstor.org/stable/10.1525/sp.2006.53.4.500?seq=1

3. Bhalla, Sahil.“ Confessions of an American cheerleader in India's glitzy cricket league." Quartz India. https://qz.com/india/401901/confessions-of-an-americancheerleader-in HYPERLINK "https://qz.com/india/401901/confessions-of-anamerican-cheerleader-in-indias-glitzy-cricket-league/"-indias-glitzy-cricket-league/

4. "No one is given IPL contract because he is someone's friend's son: Aakash Chopra" Times of India. https://timesofindia.indiatimes.com/sports/cricket/news/no-one-isgiven-ipl-contract-because-he-is-someones-friends-son-aakashchopra/articleshow/76660297.cms

5. "Indian Sports Suffers From Corruption And Nepotism, Needs Overarching Regulatory Body: RM Lodha" Outlook.

https://www.outlookindia.com/website/story/sports-news-indian-sports-suffers-fromcorruption-and-nepotism-needs-overarching-regulatory-body-rm-lodha/345138

6. Sardesai, Rajdeep. "Sport Knows No Caste But..." Breaking Views. https://www.rajdeepsardesai.net/blog/sport-knows-no-caste-but

7. Ibid

8. Dhillon, Amrit. "Why no dalit cricketers in India?" The Sidney Morning Herald. https://www.smh.com.au/world/asia/why-no-dalit-cricketers-in-india-20180531p4zim6.html

9. Ibid

10. Ibid

11. Ibid

12. Ibid

13. Sardesai, Rajdeep. "Sport Knows No Caste But..." Breaking Views. https://www.rajdeepsardesai.net/blog/sport-knows-no-caste-but 
Towards Excellence: An Indexed, Refereed \& Peer Reviewed Journal of Higher Education / Dr. H.P. Solanki/ Page 60-68

14. Saini, Aakash. "Suresh Raina Hits Back At Yuvraj Singh For MS Dhoni 'favouritism' Comments" Republic World. https://www.republicworld.com/sports-news/cricketnews/suresh-raina-slams-yuvraj-singh-ms-dhoni-favouritism-comments-cricket.html

15. Sahay, Aditya. "Is it favouritism or sheer exaggeration?" https://www.cricketcountry.com/articles/is-it-favouritism-or-sheer-exaggeration$\underline{447012}$

16. Singhal, Lakshit. "Separating sports from politics - India's need for a new law". https://www.sportskeeda.com/sports/separating-sports-from-politics-india-s-need-fora-law

\section{Dr. H. P. Solanki \\ College Director of Physical Education, N. S. Patel Arts College, Anand (Gujarat) Email: hpsolanki77@yahoo.com Mobile: 9426574553}

